\title{
Local Perspective of Housewife Women on Subjective Family Welfare
}

\author{
Laila Azkia $^{1^{*}}$ Nasrullah $^{1}$ Alfisyah ${ }^{1}$ \\ ${ }^{1}$ Department of Anthropology Sociology Education, Faculty of Teacher Training and Education, Lambung Mangkurat \\ University, Banjarmasin 70123, Indonesia \\ ${ }^{*}$ Corresponding author.Email: laila.azkia@ulm.ac.id
}

\begin{abstract}
Family social welfare studies have focused on objective welfare. Whereas there are two approaches in observing family welfare, namely objective family welfare and subjective family welfare. Objective family welfare is the family welfare approach that has been used by the government to determine a policy. Meanwhile, subjective welfare is related to self-assessment of the condition of oneself and their family and the surrounding environment. The question that is answered in this paper is how is subjective family welfare in the perspective of housewives from fishing families in Tabanio Village. Housewives are rarely studied in social welfare themes, their voices are rarely heard even though what they feel and what they value are a manifestation of their family situation. There are two main focuses in looking at the subjective welfare of the family used in this paper, namely positive values and optimism.
\end{abstract}

Keywords: Social welfare, subjective family welfare, housewives.

\section{INTRODUCTION}

Social welfare is a concept that has been discussed a lot in recent years in Indonesia. Actually, from a historical perspective, the concept of social welfare has been around for a long time, although it is better known as please help or help help. According to Bassard [1], social welfare has long roots in the Chinese, Indian, Egyptian, Greek and Jewish traditions. In England, social welfare emerged in the Middle Ages, as part of the church's activity of providing assistance to the poor and the disabled. Then in 1215 Magna Charta was born, which is a rule that guides the guarantee of protection for the British people. In America in 1662, Almshouses were built, namely houses for disabled people, and places for education and training for the poor who were still healthy [1].

The concept of social welfare comes from the Sanskrit word 'catera' which means umbrella. This meaning means that a prosperous person is a person who in his life is free from poverty, ignorance, fear and worry so that his life is safe and secure, both physically and mentally. The word social comes from the word socius, which means friends, friends, and cooperation. Social people are people who can relate to other people and their environment well. From the origin of the word social welfare can be interpreted as a condition in which people can meet their needs and can relate well to their environment [1]. Friedlander [1], defines social welfare as "the organized system of social services and institutions, designed to aid individuals and groups to attain satisfying standards of life and health, and personal and social relationships that permit them to develop their full capacities and to promote their wellbeing in harmony with the needs of their families and the community".
According to Law No.6 of 1974 Article 2 Paragraph 1 [2], social welfare is an order of life and social, material or spiritual life which is covered by a sense of safety, decency and inner and outer peace, which makes it possible for every citizen to make efforts to fulfill physical, spiritual, and social needs that are as best as possible for oneself, family and society by upholding human rights and obligations in accordance with Pancasila. The revision of the law is Law No.11 of 2009 [3], regarding social welfare, which is a condition where the material, spiritual, and social needs of citizens are met in order to live properly and be able to develop themselves, so that they can carry out their social functions. The focus of this research is welfare in the family analysis unit or family welfare.

The study of family welfare or also known as household welfare began in the 19th century by economists who were interested in observing welfare in the family analysis unit. According to Law Number 52 Year 2009 Article 6, the family is the smallest unit in society consisting of husband and wife, or husband, wife and child, or father and child or mother and child. In the same Law, Article 1 Paragraph 11 states that what is meant by family welfare is the condition of a family that has resilience and resilience and contains material physical abilities to live independently and develop themselves and their families to live in harmony in improving the welfare of birth and spiritual happiness [4]. This paper focuses more on how the subjective welfare of the family is from the perspective of a housewife. According to the Big Indonesian Dictionary (KBBI), a housewife can be defined as a woman who manages the implementation of various kinds of household chores [5]. The housewife in this paper is the wife of a fisherman in Tabanio village, Tanah Laut Regency, South Kalimantan. 


\section{THEORETICAL FRAMEWORK}

There are two approaches in observing family welfare, namely objective family welfare and subjective family welfare [4]. Objective family welfare is the family welfare approach that has been used by the government to determine a policy. Things that are seen from objective welfare are things that can be seen and measured by others such as economic conditions, education, employment, access to information and so on. So that in this case the objective family welfare looks at the aspects of meeting the needs of both basic needs, social psychological needs and development needs.

Meanwhile, subjective welfare is related to self-assessment of the condition of oneself and their family and the surrounding environment. Subjective welfare is something that is inherent in the individual. Subjective well-being is an indicator of whether a person is satisfied or not with his life [6]. Quality of Life is another term used for the concept of subjective well-being [4]. Quality of Life is something that shows a fundamental gap or difference between a person's expectations and the reality he is currently experiencing. The difference between the Subjective Quality of Life and the Objective Quality of Life is that the Subjective Quality of Life is related to feeling happy or satisfied and feeling that someone or his life is sufficient. Meanwhile, the Objective Quality of Life is the fulfillment of basic needs, social psychological needs and self-development needs in social life. This study investigates subjective family welfare which is closely related to one's satisfaction with one's own family and family conditions.

There are two theoretical approaches used in subjective welfare [7]:

1. Bottom Well-Being

This theory views that happiness and life satisfaction that a person feels and experiences depends on the number of small happiness and a collection of happy events. In particular, subjective well-being is the sum of the positive experiences that occur in a person's life. The more pleasant events that occur, the happier and more satisfied the individual is. To improve subjective well-being this theory assumes that it is necessary to change the environment of individual experience. For example, such as adequate work, friendly and safe environment, decent salary income.

2. Top-Down Theories Subjective

welfare experienced by a person depends on the way the individual evaluates and interprets an event or event in a positive light. This theory assumes that it is the individual who can determine or hold authority, what events can create psychological well-being for him. This approach considers the type of personality, attitudes, and the ways used to interpret events. So that to improve subjective well-being requires efforts that focus on changing one's perceptions, beliefs and personality traits.

\section{METHOD}

This research uses qualitative research methods. The data source was selected by using purposive method or criteria. Housewives are a group of people who rarely speak out either because their voices are limited as what Spivak calls subalterns or because their voices are not represented properly [8]. This paper selects the housewife stairs as the informant because they want to help voice what a housewife assesses herself, her family and the environment. The criteria for housewives who are informants in this paper are (1) having been married for more than 5 years, (2) their husbands work as fishermen. There were 4 informants that researchers interviewed in depth to find subjective family welfare. The research location is in Tabanio village, Takisung District, Tanah Laut Regency, South Kalimantan.

\section{RESULT AND DISCUSSION}

Tabanio is a village located in Takisung District, Tanah Laut Regency, South Kalimantan. Work as a fisherman is the job of the majority of the population in Tabanio village. According to the Tabanio Village Profile, from 2014-2015 the population based on occupation was 2,436 people and 1,132 people worked as fishermen or around $46.5 \%$. This is supported by the geographical location of the village of Tabanio which is on the coast, where the west is bordered by the Java Sea. It is about $17 \mathrm{~km}$ from Tabanio village to the sub district capital. On average, the people who live in Tabanio village are indigenous people. They were born, worked and married in Tabanio.

The approach that researchers use in viewing subjective well-being is Top-Down Theories, where researchers see how informants interpret or interpret themselves at this time. The process that the author explores is the positive self-esteem that housewives have regarding themselves, the family, the neighborhood where they live. The positive selfesteem referred to here is how the informant's opinion or assessment is related to himself, his family and the environment in which he lives. First, the author looks at the informants' view of the environment in which they live. Informant A viewed that he could not develop if he continued in Tabanio village, the difficult economic life of his family, uncertain husband's income and increasing family needs made him decide to leave the village and leave for work. He then went to East Kalimantan, to be precise in Grogot to work. Her husband did not approve of her decision, so the decision made her household falter and her husband remarried. Although in the end she divorced, informant A did not regret the decision, thanks to working overseas she was able to pay for the needs of her children. Immigration for economic reasons is an action that is mostly done by women in Tabanio village. Even though some of their husbands do not agree with this, they are still optimistic that what they do will bring success. Now he returns to Tabanio village to occupy his old house, while some of his children are working and still in school. His son also followed in the footsteps of his mother, namely informant $\mathrm{A}$, to work overseas in order to improve the quality of life. After returning to Tabanio village, informant A continued his life by working to bake cakes and sell them. 
The money from the wander runs out for school fees and buys her children's needs. Return to his hometown because he feels comfortable living in the village. In the village, the relationship between neighbors is well established, mutual help between residents, close kinship. Such sociopsychological reasons made him return to his hometown, namely Tabanio Village. Moving or immigration was actually only for the economy. As said by the informants, although they are economically more prosperous if they live and work outside the village, socially, psychologically, they are not comfortable living outside the village. Proximity to family, closeness to neighbors and mutual help with others make them comfortable living in the village, and these things cannot be found if they live outside the village. "When sick, no one visited", that was an expression of the informant's sadness when telling about his condition when he first migrated.

Another informant, B, saw the area where he lived as an uncomfortable place for people with middle to lower economic conditions who were the majority of Tabanio villagers. One of the reasons for this is because it is difficult for people to get the necessities of daily life, one of which is access to clean water and health. Clean water should be the right of the community, but not in this village. They cannot consume well water because it is salty and not clear. So they only use well water for bathing and washing. Tabanio villagers are forced to buy clean water. Every day there are clean water sellers who ride motorbikes selling clean water with conductors for their consumption. They have to pay to get clean water that is suitable for consumption, Rp. 5,000 per 3 conductors is the price of clean water in Tabanio village. This kind of thing made the informants say "Nothing is free here, everything is paid for", not only related to clean water but also related to health services, hygiene and education. Complaints related to the high cost of medical treatment, the cost of giving birth and not maintaining cleanliness in the village were the things informant B assessed the environment in which he lived. The fishermen in Tabanio village usually go out to sea for between 10 and 15 days. On average, they become crew members of ships or vessels that belong together. Like informant C's husband who goes to sea with 5 of his colleagues in 1 ship. The length of time the husband goes to sea makes the wife, who is a housewife, look for her own activities. The housewives finally developed a close relationship between housewives and fishermen's wives who also lived in Tabanio Village. They usually spend time with neighbors around them when their husbands go to sea. Just to cook together then eat together at teras, gather in religious events, go together either to the market or to village events and help each other if a neighbor is in need is one form of activity that mothers do to spend their time when their husbands go to sea. The closeness to the neighbors makes the housewife feel less lonely when her husband goes to sea. Informant $\mathrm{C}$ assesses the closeness between neighbors as a positive value from the environment where he lives.

The husband's job as a fisherman who goes to sea is not a job with definite and satisfying results according to the informant. The environment that has changed is not what it used to be. If in the past, fishermen were said to be prosperous, at least fishermen were able to meet the daily needs of the family. But now that has changed. Not to mention that the weather, which is often erratic and sometimes dangerous, makes fishermen's wives worried about their husband's condition while at sea. The difficulty of obtaining fish, the fluctuating price of fish, made their needs not properly fulfilled. Housewives are not satisfied with the income their husbands earn, so some of them help meet household needs.

The perception that housewives in Tabanio village have regarding the condition of themselves, their families and their environment are influenced by socio-economic conditions. Housewives have a positive value on social life in their village. Good relations between residents, helping each other and forgiving each other if there are mistakes make housewives have a good perception. However, in terms of subjective welfare, he lacks optimism. This is because the main livelihood of the people in Tabanio village, namely fishermen, does not generate a steady and sufficient income while their needs are increasing. So that it makes housewives feel less optimistic if they continue to be in the village.

Good perceptions of the social environment in the village indicate the feeling of happiness that housewives in Tabanio Village have. Happiness is a major aspect of subjective well-being [9]. The main determinant of a person's happiness is not just an economic problem. But good kinship, smooth social interaction and solidarity or high help among residents in the village make housewives feel happy living in the village and want to return to the village again when they are tired of traveling.

The housewife in Tabanio Village is satisfied with her current life. These results are consistent with the results of studies comparing the welfare of families in urban and rural areas. Namely that the subjective welfare of families in urban areas is higher than the subjective welfare of families in rural areas [10]. The economic situation is less wellestablished so it is difficult to meet daily needs. This has resulted in the desire to leave the village of origin to migrate and improve the economic situation. However, good social relations make housewives feel at home living in the village and want to return to the village after leaving.

The results of the subjective welfare research are provisional. This is because subjective well-being is influenced by momentary events [11]. The momentary events referred to are such as problems in the household, thoughts that are disturbing, whether needs are met or not, social interactions that exist with people around them and so on. This incident can give birth to various kinds of feelings, such as feelings of annoyance, disappointment, happiness or even satisfaction or dissatisfaction. These feelings are what influence a person's assessment of his life or subjective well-being. And these feelings influence a person's assessment of his family or subjective family welfare. 


\section{CONCLUSION}

Subjective family welfare of housewives in Tabanio village is quite good. They have a positive value on their social life. However, housewives do not have optimism, one of which is because of the economic difficulties they have. However, they still have optimism to succeed, unfortunately this optimism is in conditions outside their village, not optimism for success in their village. So that they have the desire to move from their village or migrate to improve the economic conditions of the family. But the social relations that are well established in the village make villagers who have migrated to return to their villages. The local perspective of housewives on subjective family welfare depends on their perceptions of their social and economic conditions.

\section{REFERENCES}

[1] A. Fahrudin, Pengantar Kesejahteraan Sosial. Bandung: Refika Aditama, 2014.

[2] Sekretariat Negara, Undang-Undang Republik Indonesia Nomor 6 Tahun 1974 Tentang. Jakarta, 1974.

[3] S. Negara, Undang-Undang Republik Indonesia Nomor 11 Tahun 2009 Tentang Kesejahteraan Sosial. Jakarta, 2009, hal. 19.

[4] H. Puspitawati, "Pengertian Kesejahteraan dan Ketahanan Keluarga," in Gender dan Keluarga : Konsep dan Realitas di Indonesia, Bogor: IPB Press, 2015, hal. 18.

[5] H. Junaidi, "Ibu Rumah Tangga: Streotype Perempuan Pengangguran," An Nisa'a, vol. 12, hal. 77-87, 2017.
[6] D. Handayani, Y. Hidayat, dan L. Azkia, "Kesejahteraan Subjektif Lansia Di Panti Sosial Tresna Werdha Budi Sejahtera Provinsi Kalimantan Selatan," J. Padaringan, vol. 2, no. 1, hal. 156-163, 2020.

[7] J. Ariati, "Subjective Well-Being (Kesejahteraan Subjektif) Dan Kepuasan Kerja Pada Staf Pengajar (Dosen) Di Lingkungan Fakultas Psikologi Universitas Diponegoro," J. Psikol., vol. 8, no. 2, hal. 117-123, 2010, doi: 10.14710/JPU.8.2.117-123.

[8] L. Azkia, "Ngisap Rokok Kretek : Action Kaum Subaltern ( Studi Atas Gerakan Kretek)," Padaringan, vol. 1, no. 1, hal. 86-96, 2018.

[9] S. Hafiza dan M. Mawarpury, "Kesejahteraan Subjektif pada Pemulung: Tinjauan Sosiodemografi," Gadjah Mada J. Psychol., vol. 5, no. 2, hal. 139, Okt 2019, doi: 10.22146/gamajop.49945.

[10] I. Islamia, E. Sunarti, dan N. Hernawati, "Tekanan Psikologis Dan Kesejahteraan Subjektif Keluarga Di Wilayah Perdesaan Dan Perkotaan," Anfusina J. Psychol., 2019, doi: 10.24042/ajp.v2i1.4312.

[11] A. Cahyat, C. Gonner, dan M. Haug, Mengkaji Kemiskinan dan Kesejahteraan Rumah Tangga Mengkaji Kemiskinan dan Kesejahteraan. Bogor: Center for International Foresty Research (CIFOR), 2007. 